\title{
A STUDY OF THE COMMON ORIGIN OF LINGUAL AND FACIAL
} ARTERY FROM THE EXTERNAL CAROTID ARTERY

\author{
M.Anuradha *1, S. Chitra ${ }^{2}$. \\ ${ }^{* 1}$ Assistant Professor, Department of Anatomy, Stanley Medical College, Chennai, Tamilnadu, \\ India. \\ 2 Professor and HOD, Department of Anatomy, Stanley Medical College, Chennai, Tamilnadu, \\ India.
}

\section{ABSTRACT}

Background: The common carotid arteries provide the major source of blood to the head and neck region. In the present study, we studied about the variation in the origin of lingual and facial artery and specifically, the linguofacial trunk. The knowledge of this anatomical variation is important in the surgeries of head, neck and face and also for the radiologists to understand and interpret carotid system imaging when undertaking cerebral angiography.

Materials and Methods: 30 cadavers of both sexes have been used in the current study. Head and neck dissections of these cadavers were done in the department of anatomy, Stanley Medical College Tamilnadu.

Results: In present study the linguofacial trunk was observed unilaterally in 3 cadavers. Conclusion: knowledge about this variation is important to anatomists, surgeons and radiologists.

KEY WORDS: Common carotid artery, External carotid artery, Lingual artery, Facial artery, linguofacial trunk.

Address for Correspondence: Dr. M.Anuradha, Assistant Professor,Department of Anatomy, Stanley Medical College, Chennai, Tamilnadu, India. E-Mail: dranurac@yahoo.com

\begin{tabular}{|l|l|}
\hline \multicolumn{3}{|c|}{ Access this Article online } \\
\hline Quick Response code & $\begin{array}{l}\text { Web site: International Journal of Anatomy and Research } \\
\text { ISSN 2321-4287 } \\
\text { www.ijmhr.org/ijar.htm }\end{array}$ \\
\cline { 2 - 3 } & \multicolumn{2}{|c|}{$\begin{array}{l}\text { Accepted: 02 Mar 2017 } \\
\text { Dol: 10.16965/ijar.2017.132 }\end{array}$} & $\begin{array}{l}\text { Received: 28 Jan 2017 } \\
\text { Reer Review: 01 Feb 2017: None }\end{array}$ & $\begin{array}{l}\text { Published (O): 31 Mar 2017 } \\
\text { Published (P): 31 Mar 2017 }\end{array}$ \\
\hline
\end{tabular}

\section{INTRODUCTION}

The Common carotid artery normally divides into external and internal carotid artery at the level of upper border of thyroid cartilage. The internal carotid artery runs a straight course from the carotid bifurcation to the entry in the temporal bone without branching. External carotid artery $(E C A)$ is one of the terminal branches of common carotid artery and it supplies anterior branches to head and neck structures including the superior thyroid, lingual and facial arteries. The lingual artery is the second branch of external carotid artery arising from its front, opposite the tip of greater cornu of hyoid bone [1].
The facial artery normally arises from the front of external carotid artery just above the tip of greater cornu of hyoid bone. These arteries originate separately from the ECA in $77.8 \%$ of cases [2]. Sometimes the lingual artery arises from common trunk with the facial artery as linguofacial trunk $[3,4]$.

This Knowledge of the possible variations of the external carotid artery is important, during head and neck surgery such as extra oral ligation of lingual artery, plastic and reconstructive surgeries of face and lip. Selective arterial embolization to reduce the vascularity of the tumours of the head, neck and face [5]. It is also essential 
for radiologists to understand and interpret the carotid system imaging [6].

\section{MATERIALS AND METHODS}

This study was done on thirty embalmed human cadavers. These specimens were collected from Department of Anatomy, Stanley Medical College, Chennai, Tamilnadu. Routine dissection method was followed and the distance between carotid artery bifurcation and origin of linguofacial trunk was measured by using digital caliper.

\section{RESULTS}

Out of the 30 cadavers, the anomalous origin of lingual and facial artery as a common trunk was found in 3 cases on right side.

The lingual artery was found to arise from the anteromedial surface of the external carotid artery as a separate branch in $90 \%(27 / 30)$ of the cases. It was found to share a common trunk with the facial artery as linguofacial trunk in 10\% $(3 / 30)$ of the cases. The facial artery was found to arise from the anteromedial surface of the external carotid artery as a separate branch in $90 \%(27 / 30)$ of the cases and it shared a common trunk with the lingual artery in $10 \%$ (3/ $30)$ of the cases. The distance between carotid artery bifurcation and common origin of linguofacial trunk was $1.9 \mathrm{~cm}$ in case $A, 1.2 \mathrm{~cm}$ in case $B$ and $0.8 \mathrm{~cm}$ in case $C$

The incidence of linguofacial trunk in the present study was $10 \%$.

The mean level of origin of linguofacial trunk from carotid artery bifurcation was $1.3 \mathrm{~cm}$.

Fig. 1 and Fig. 2: The Linguofacial trunk arising from the External carotid artery.

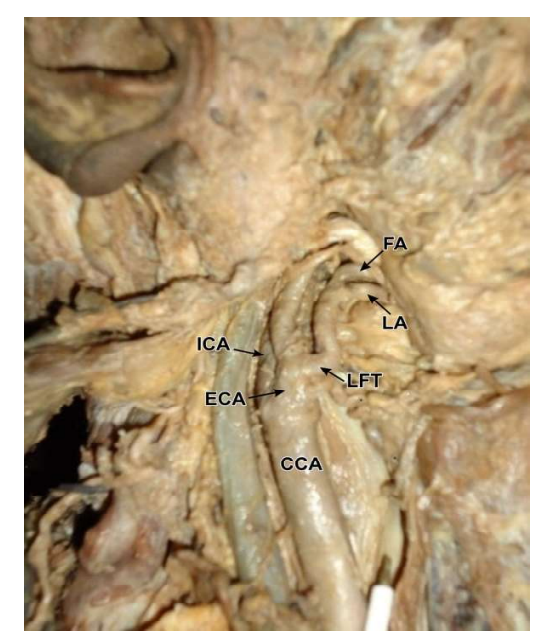

Int J Anat Res 2017, 5(1):3656-58. ISSN 2321-4287

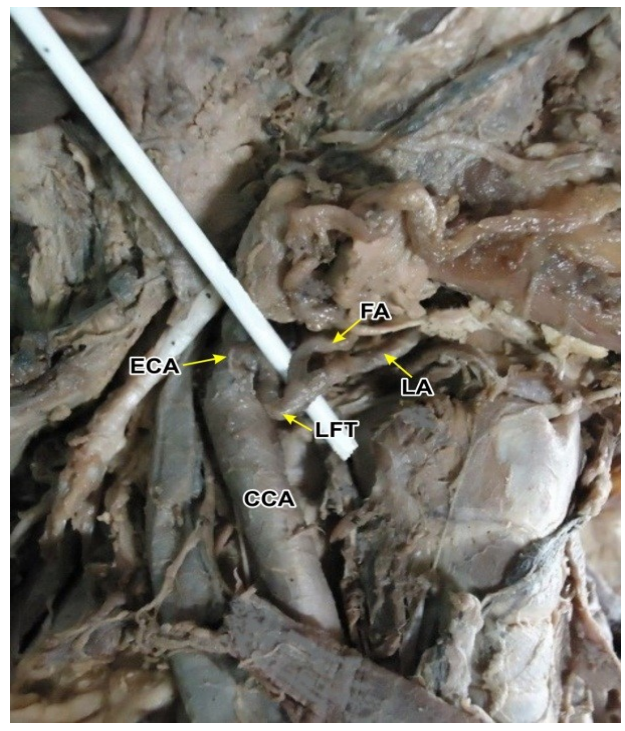

\section{DISCUSSION}

The incidence of linguofacial trunk was reported by various authors. The lingual artery arises from a common trunk with the facial as a linguofacial trunk was found in $14 \%$ of the cases by Lappas [7], in $11.3 \%$ of the cases by Vishnu gupta et al [8], in $7.5 \%$ of the cases by Ozgur et al [9], in $15.38 \%$ of the cases by Abhijeet yadev et al [10] and it was found in $10 \%$ of the cases in the present study.

Nirmala devi $\mathrm{M}$ et al reported that linguofacial trunk arose $3 \mathrm{~cm}$ above the carotid bifurcation [11]. Pantoja G C et al observed linguofacial trunk on left side located $1.2 \mathrm{~cm}$ from the bifurcation of common carotid artery [12]. In Present study the mean level of origin of linguofacial trunk from the bifurcation of carotid artery was $1.3 \mathrm{~cm}$.

The Facial Artery Musculo-Mucosal (FAMM) flap was introduced by Pribaz J et al [13] used for reconstruction of oronasal fistulas and closure of soft tissue defects in the mandibular vestibule. The FAMM flap use is limited by variations in the course of the facial artery. Therefore knowledge of the origin, course and branching pattern of the facial and lingual artery is significant for face, head and neck surgeries and also for the radiologist to understand and interpret carotid system imaging when undertaking cerebral angiography.

\section{CONCLUSION}

The knowledge of vascular anatomy of the lingual and facial artery is necessary for surgical, radiologic and diagnostic procedures in the 
head and neck region. The present study is to provide useful information about the origin, course and anatomical relations of the linguofacial trunk for clinical application in different fields related with head and neck surgery.

\section{ABBREVIATION}

$$
\begin{array}{ll}
\text { CCA } & \text { - Common Carotid Artery } \\
\text { ECA } & \text { - External Carotid Artery } \\
\text { ICA } & \text { - Internal Carotid Artery } \\
\text { LFT } & \text { - Linguofacial Trunk } \\
\text { LA } & \text { - Lingual artery } \\
\text { FA } & \text { - Facial artery }
\end{array}
$$

\section{Conflicts of Interests: None}

\section{REFERENCES}

[1]. Williams PL, Bannister LH, Berry MM; Gray'sAnatomy. In: Arteries of limbs and cardiovascular system.Thirty eighth edition. London: Churchill Livingston, 1995;1516-1517.

[2]. Mata JR, Mata FR, Souza MC, Nishijo H, Ferreira TA. Arrangement and prevalence of branches in the external carotid artery in humans. Italian Journal of Anatomy and Embryology.2012;117(2):65-74.

[3]. Gray $\mathrm{H}$, Anatomy, descriptive and surgical, second edition, Blanchard \& Lea, Philadelphia, 1862;37476.

[4]. Midy D., Maures B., Vergnes P., Caliot P.A. Contribution to the study of the facial artery, its branches and anastomoses; application to the anatomic vascular bases of facial flaps. Surgical and radiologic anatomy. 1986;8(2):99-107.
[5]. Sanjeev IK, Anita H, Aswini M, Mahesh U, Rairam $\mathrm{GB}$, Branching pattern of external carotid artery in humans. Journal of Clinical and Diagnostic Research. 2010;4:3128-3133.

[6]. Kishve PS, Kishve SP, Joshi M, Aarif SM,Kalakoti P; An unusual branching pattern of common and external carotid artery in a human cadaver: a case report. The Australasian medical journal, 2011;4(4):180.

[7]. Lappas DA, Kamberos SP, Gisakis IG, Takis CH,Lykaki $\mathrm{G}$. Anatomic study of the variations in the origin of the branches of the external carotid artery. Beta Medical Arts 2002;81.

[8]. Vishnu Gupta, Rakesh Agarwal Anomalous Branching Pattern of the External Carotid Artery in Cadavers International Journal of Scientific Study, April 2014;2(1).

[9]. Ozgur Z, Govsa F, Ozgrs T. Assessment of origin of characteristics of the front branches of ECA. Journal of Cranio Facial Surgery.2008;19:1159-1166.

[10]. Abhijeet Yadav, Mukul Yadav, Asha Dixit A Research on The Incidence of Linguofacial Trunk Arising From External Carotid Artery in Adult Cadavers. Scholars Academic Journal of Biosciences (SAJB) 2014;2(10):709-710.

[11]. Nirmala devi M, Sruthi G. Linguo-facial trunk. A case report. Anatomica Karnataka. 2010;4:54-56.

[12]. Pantoja G.C, Coronado G. C, Aravena T. P, suazo. G. I. Lingual-facial trunk arising from the external carotid Artery: A case report. International Journal of Morphology, 2014;32(3):1108-1110.

[13]. Pribaz J., Stephens W., Crespo L., Gifford G., A new intraoral flap: facial artery musculomucosal (FAMM) flap, Plastic Reconstruction Surgery, 1992;90(3):421-29.

How to cite this article:

M.Anuradha, S. Chitra. A STUDY OF THE COMMON ORIGIN OF LINGUAL AND FACIAL ARTERY FROM THE EXTERNAL CAROTID ARTERY. Int J Anat Res 2017;5(1):3656-3658. DOI: 10.16965/ ijar.2017.132 